\title{
America, Brexit and the Security of Europe
}

\section{Wyn Rees}

\begin{abstract}
The Obama administration played a surprisingly interventionist role in the UK referendum on membership of the European Union, arguing that a vote to leave would damage European security. Yet this article contends that US attitudes towards the EU as a security actor, and the part played within it by the UK, have been much more complex than the US has sought to portray. While it has spoken the language of partnership, it has acted as if the EU has been a problem for US policy. The UK was used as part of the mechanism for managing that problem. In doing so America contributed, albeit inadvertently, to the Brexit result. With the aid of contrasting theoretical perspectives from Realism and Institutionalism, this article explores how America's security relationship with the UK has helped to engineer a security situation that the US wanted to avoid.
\end{abstract}

\section{Keywords}

United States, United Kingdom, European Union, Brexit, Security, Special Relationship

The United States watched with steadily mounting concern as the UK drew closer to its referendum over remaining or withdrawing from the European Union (EU). This so-called 'Brexit' debate had been a long mooted possibility in British domestic politics (Glencross 2015; Oliver 2015, 88). It was activated by Prime Minister David Cameron's promise that, if the Conservative Party won the General Election of May 2015, his government would conduct a renegotiation of the terms of UK membership of the EU, followed by a referendum on membership within two years (Cameron 2013; See also Cameron 2015). The subsequent Conservative victory led the Prime Minister to undertake a rapid renegotiation followed by the referendum on 23 June 2016. A majority of $51.9 \%$ of the population voted for exit. Cameron duly announced that he would step down to make way for Theresa May to negotiate the process of the UK's withdrawal.

During the run up to the referendum the Obama administration was unequivocal in opposing Brexit and warning of the risks for the EU. As early as January 2013, Philip 
Gordon, the Assistant Secretary for European Affairs, spoke out on the subject, affirming that, 'We welcome an outward looking European Union with Britain in it. We benefit when the EU is unified, speaking with a single voice, and focused on our shared interests around the world and in Europe' (Borger et al, 2013). This sentiment was reiterated by the US Ambassador in London, Louis Susman, in March of the same year. It was given added weight by President Obama's remarks at the Group of Seven meeting in Bavaria in June 2015 and then by Secretary of State John Kerry at the Munich Security Conference in February 2016. The President visited London between April 22-23 to deliver a number of speeches warning Britain against leaving the EU. These interventions were further amplified when a clutch of former Secretaries of Defence, Secretaries of State and National Security Advisers sent a letter to The Times arguing against leaving the EU, (Brzezinski et al. 2016, 26). It was evident that Brexit raised fears amongst US political elites across the political spectrum.

Brexit played into a bigger political issue for the US, namely its relationship and attitude towards the EU (Wintour 2016). The US stance towards Brexit created an impression that the US has always been an unambiguous supporter of the role of the EU as a security actor. In reality, however, there has been a much more ambiguous attitude by successive US administrations towards the EU role in defence and security. The US has long struggled with the issue of how to treat the EU: as a security partner or as a problem. Washington has spoken the language of partnership, yet acted as if the EU was a source of difficulty to be managed. America's relationship with the UK was treated as the mechanism for managing that problem. As a leading defence and security actor within the EU, the UK has provided the US with a means to influence and constrain the Union's activities. In turn, this has played into UK scepticism of the EU's continental and global security functions. It fostered a UK self-perception that it was more than just a European power.

This ambivalence in American attitudes has long existed. It was been most prevalent on the right of the American political spectrum, in think tanks such as the Heritage Foundation, the American Enterprise Institute and the Cato Institute (Byrne 2016). It was evident in the speeches of US Republican presidential candidate Donald Trump. In the words of three of its leading commentators, 'If the British people vote to leave the EU, the result should be welcomed in Washington...' (Gardiner et al, 2015). This particular discourse has considered the EU to be inimical to American interests. It has regarded Brexit as an opportunity to invigorate the so-called Anglo-American 'Special Relationship". 
This article argues that US attitudes towards the EU as a defence and security actor, and the role it assigned to the UK, played an important part in the outcome of the Brexit referendum. Washington's scepticism of the EU contributed, albeit inadvertently, to UK withdrawal because it cultivated a view that the Union did not serve Britain's security interests. With the aid of theoretical perspectives from Realism and Institutionalism, this article will begin by explaining the development of US attitudes towards the EU in transatlantic security. The second section investigates how America used the UK to constrain the potential role of the EU. The third relates how the US privileged a bilateral security relationship with the UK. Finally, the article will look at how the US treated the UK as part of its strategy for managing the EU's role in global security affairs.

\section{A US order founded upon Atlanticism and European integration}

In order to understand the ambivalence that underpinned US attitudes towards the EU, and thereby contributed to Brexit, one needs to trace the post-war liberal order that it constructed. In the face of a perceived threat from the Soviet Union, the US built an 'Atlantic' order with a group of west European states, with whom it shared 'overlapping values, converging interests, and common goals' (Serfaty 1997, 1. See also Lundestad 2003; Applebaum 2016, 21). America stationed conventional forces on the continent and extended its nuclear deterrent over these allies. Washington appreciated that to lead a group of sovereign and democratic states it had to enable them to feel that their voices were being heard and their interests protected (Hirschman 1970).

A 'Constitutional Atlanticism' was created through a deliberate organisational architecture: in the expectation that its durability would be greater than that of an order resulting from a temporary balance of power (Risse-Kappen 1995; Ikenberry 2004, 611). The US assumed the mantle of 'first among equals' within NATO and placed this principle at the heart of the architecture. In return America accepted limits upon the exercise of its own power, a practice described as 'self-binding' (Kupchan 1998, 46; Deudney and Ikenberry 1999, 182). America behaved as a benign actor that underpinned the order with its military and economic strength, but exhibited no aggressive intentions towards its allies (Pape 2005, 9). NATO became a means to construct complex patterns of cooperation between western countries and to reduce pressures for competition (Ikenberry 1988-89, 44). This Atlanticist strategy served to lock its members into path dependent courses of action that restricted their opportunity to break away and pursue unilateral advantage (Ikenberry 2001, 246). 
Atlanticism mitigated the weaknesses of European states and enabled them, under American leadership, to act cohesively. Whilst the US commitment to Atlanticism was relatively consistent, its support for European integration proved much more ambiguous. On the one hand, America voiced encouragement for integration, seeing it as a means to build up the unity of the continent, foster economic strength and resolve long-standing intra-European tensions (Philipart and Winand, 2001). On the other hand, the US was aware that its own lack of membership reduced its capacity to influence the trajectory of the European Community (later the European Union, EU). There was always the danger that European integration, whilst initially dependent on the security provided by Atlanticism, could evolve into an institutional framework antagonistic towards the US (Brimmer 2007). In such a scenario Europe would grow apart from, and in tension with, its 'American pacifier' (Joffe 1986). In short, Atlanticism and European integration had the potential to come into conflict with one another (Kissinger in Lundestad 2003, 178).

Structural Realists have provided one source of theoretical explanation for America's suspicions of the EU. They argue that as the dominant power within the international system, the US experiences efforts by other countries to counter-balance its strength. As the EU grew in maturity it would seek to act in this way and, as a potential source of competition, the US would view it as rival to be resisted (Waltz, 2000). During the Cold War the threat from the Soviet Union and the Warsaw Pact forced the interests of the US and Europe into alignment, but in its aftermath their interests have diverged. Paul (2005) argues that post-Cold War Europe has been unnerved by America's over-arching strength and has sought to offset its position of inferiority. Posen (2006) contends that European defence efforts represent an attempt to challenge American hegemony by a policy of 'hard' balancing. Evidence of hard balancing is seen in the attempt since 1999 to create a European Security and Defence Policy (ESDP, subsequently renamed Common Security and Defence Policy, CSDP) capable of acting independently from NATO (Howorth 2007).

An alternative interpretation has seen the 'problem' of the EU, for the US, residing not in its potential strength but in its manifold weakness. Theorists have regarded the EU as either too weak to present a source of challenge or too insignificant for America to care about its protection (Mearsheimer 2001, 46). Lacking the means to counter-balance the US, the EU has sought to offset American strength through alternative means. Economic 'soft balancing' through the creation of the Euro, or the use of international institutions, such as the UN, have been designed to frustrate the exercise of American power. Where there have been investments in CSDP capabilities, these have been designed, to 'complement, rather than compete', with the structures of the US and NATO (Brooks and 
Wohlforth 2005, 92). This is borne out by the experience of CSDP operations. These have been missions that have taken over non-threatening environments bequeathed by NATO, such as in Bosnia and Kosovo; or conducted in far-flung theatres such as the Democratic Republic of Congo. They have been limited in scale, predominantly civilian operations and have concentrated upon post-conflict reconstruction and humanitarian tasks (Rees, 2011, 77-84).

Within this Euro-Atlanticist framework the UK occupied a key role. It was instinctively Atlanticist in disposition, 'tak(ing) up a position that is dependent upon a perception of US preferences' (Dunne 2004, 909). Britain has regarded US involvement as vital in ensuring the security of Europe. America has provided leadership around which others powers could coalesce (Blair 2010, 676), as well vital capabilities such as satellite intelligence, precision-guided munitions, all weather attack capabilities and networkconnected forces. Britain saw itself as serving as a bridge between the two halves of the Atlantic, encouraging greater European efforts in defence but in ways that complemented rather than undercut the Alliance. As noted by former Foreign Secretary David Milliband, 'one of the key elements of our relationship (with the US) is Britain's strength in Europe', (Milliband 2010, 2e). Lacking the ability to steer European integration, the US relied upon the UK to constrain the EU in ways congruent with its interests.

The fact that Britain will now leave the European Union strikes at the heart of this transatlantic order. One of the two key European military powers will remove itself from part of the multilateral security architecture. The article will proceed to look at how American ambivalence towards EU security and counter-terrorism matters contributed to Britain's decision to withdraw.

\section{Brexit and European Union Security}

The US attitude towards Brexit was related to its complex attitudes towards the EU'S defence and broader security competences. It exposed the double mindedness of the US towards the EU as well as the role it has wanted the UK to play within this triangular relationship.

In the past, the US supported the UK's emphasis on intergovernmental rather than supranational defence cooperation. The US was sympathetic to the UK's reluctance to become part of the integration project and its desire to preserve its sovereignty (George 
1988). Both countries were sceptical of the EU's capacity to overcome its plurality of views and generate the political will to act. The UK championed EU enlargement to central and east Europe as part of its strategy to build a broad yet shallow Union. Its aim was to dilute the inner core of west European countries and weaken the momentum for closer integration (Leigh 2015). It also had the benefit, in American eyes, of championing the membership of states from central and eastern Europe who exhibited a staunchly Atlanticist outlook.

The US reinforced the UK'S own low regard for the EU as a defence actor. By criticising the level of European defence spending by states such as Germany, Spain and Italy, the US nurtured a discourse that its allies were making an insufficient contribution to collective defence (Molling 2015). The US called for a stronger capability amongst EU states to deploy military forces for operations other than territorial defence, whilst simultaneously expressing suspicions of efforts pursued outside the confines of NATO (Pape 2005). Successive US administrations bemoaned Europe's continued reliance upon America. The George W. Bush administration openly disparaged Europe's lack of military prowess: for example, the 2003 defence meeting between Germany, France, Belgium and Luxembourg was labelled 'the chocolate makers summit' to denote its lack of substance. When Defense Secretary Robert Gates retired from the first Obama administration he berated the Europeans for what he alleged to be their policy of demilitarisation (Gates 2011).

The UK endorsed America's calls for enhanced European military capabilities: for example, it was one of the leading states calling for the implementation of the European Capabilities Action Plan. London contended that the Union had been overly fixated with institution building, at the expense of investing in defence equipment, research and development. What the US did not fully appreciate was the corrosive effect that its policies were having upon the UK's attitudes towards the EU. Despite being the most important defence player, the UK eschewed a leadership role within Union (Marsh 2013, 186; Wallace 2005, 65). Only in the creation of the ESDP at St Malo and then in Helsinki did the UK show real leadership in EU defence and this energy was rapidly dissipated. Instead UK initiatives have tended to be bilateral in nature with countries like France, such as the formation of an Air Group and the Lancaster House agreement in 2010 (Treaty 2010).

The UK has actively sought to constrain developments that would put US leadership within NATO at risk. As the most powerful military actor in Europe, alongside France, the UK's involvement has been essential to defence initiatives and it has made no secret of 
its determination to uphold the central role of the Alliance. Furthermore, it was agreed in the so-called 'Berlin Plus' framework that EU military initiatives could be commanded by a headquarters detached from the NATO military structure. Under this arrangement, the Deputy Supreme Allied Commander Europe (D-SACEUR) would be put in charge of European military forces. As the UK held the D-SACEUR appointment, it gave them a decisive voice in preventing operations that challenged America's leading role.

When EU initiatives in defence caused palpitations in Washington, it was the UK that assuaged those fears. It was Prime Minister Tony Blair, for example, who alleviated US concerns about the launch of the ESDP. US Secretary of State Madeleine Albright was worried that ESDP could duplicate NATO planning and decision-making structures, decouple trans-atlantic collective defence and discriminate against states that were members of the Alliance but not of the EU (Albright 1998). Britain went on in 2003 and then in 2011 to veto EU proposals for an integral planning headquarters that threatened to impinge on the unique capabilities of NATO. America grew accustomed to counting on what Witney (2016) describes as the UK's 'largely obstructive' role in European defence'.

Throughout the post-Cold War era, France and Germany have sought to develop more autonomous EU defence capabilities from the Atlantic Alliance. The US has viewed these initiatives as detrimental to its own interests: from the creation of the Eurocorps in the early 1990s to the Helsinki Force Goals and beyond. Amidst the tension of the Brexit referendum, French and German attention returned to building closer defence cooperation (Emmot 2016). The objective of these two countries in the short term is to secure both an EU command structure and common military assets that could be used for operations in areas contiguous to their territories or at distance overseas. Britain's monopoly of the D-SACEUR role would also be less important and might even be at risk (Chalmers 2017, 6). One analyst has warned that the problem of a European chain of command could set off a train of events that might lead to 'a defence planning process (in the EU) running parallel to that of NATO' (Johnston 2016: see also Coffey 2013).

From other leading figures within the Union have come a more ambitious goal, namely the creation of an EU military force. In March 2015 EU Commission President JeanClaude Juncker called for such a force (Sparrow 2015) and repeated this in a speech to the European Parliament on 14 September 2016 (European Commission 2016). After the Brexit decision, Vice-President of the European Commission, Federica Mogherini, echoed the call for an EU military force to be assembled (Waterfield and Willan 2016, 8. See also EU Global Strategy 2016). This vision of the EU as a major military actor represents the vision of European federalists. It has been given added impetus by the Brexit result for 
those who envisage a leap forward in European integration as an antidote to the prevailing pessimism within the Union.

The US also fears the damage that Brexit will inflict on the broader, non-military, security policies of the EU. Since the 9/11 attacks, the US has knitted together a pattern of counter-terrorism cooperation with all 28 EU countries, as an alternative to negotiating agreements with individual states. This has been made desirable by the Union's unique, 'communitarised' competences in trade and internal security. These competences range in scope from data sharing and judicial cooperation to airline passenger records and container security protocols. Such cooperation may be damaged by Britain's departure, as President Obama warned during his visit to London in April 2016 (Obama, 2016). Brexit removes from the Union the influence of a major counterterrorism actor sympathetic to US priorities as well as reduces the intelligence that the UK will have to share.

In this policy sphere as in others, past US actions and attitudes contributed to this outcome. In counter-terrorism the US has too often treated the EU as a source of its insecurity, rather than as its partner in tackling the threats. For instance, the US alleged that its own domestic vulnerability stemmed partly from European citizens travelling to its shores. Secretary of the Department of Homeland Security, Michael Chertoff, named Europe as a major source of threat (Weaver 2008). Similarly, voices were raised in the US Congress against the continuation of visa-free travel from the EU. The 2007 US Strategy for Homeland Security placed a series of security demands upon the EU, but was reluctant to offer reciprocal cooperation. Analysts have shown that it has taken a long time for a more equitable US-EU relationship to evolve; one in which Europe has been treated as an ally in the shared struggle against violent extremism (Anagnostakis 2014).

This American scepticism of the value of counter-terrorism cooperation with the EU was mirrored in the UK's own Brexit referendum. Amongst those advocating withdrawal were senior figures in the British security services who questioned the value of the EU in fighting terrorism. The former Director of the Secret Intelligence Service (SIS), Sir Richard Dearlove, argued that the Union's intelligence sharing fora were of little importance and that UK security rested on its relationship with America (Prospect Magazine Online 2016). On the other side of the debate was the then Home Secretary, Theresa May (The Times 2016), former Commissioner of the Metropolitan Police Sir Bernard Hogan-Howe, former Director of SIS Sir John Sawers and two former Directors of the domestic intelligence agency MI5, Jonathan Evans and Dame Eliza Manningham- 
Buller. They countered that EU membership gave the UK access to valuable counterterrorism databases such as in Europol, the Schengen Information System II, Eurodac, as well as judicial cooperation in Eurojust. Exiting from the Union would put these interests at risk and might necessitate complex negotiations to preserve rights of access.

Therefore, across the spectrum of defence and security policy, America's sceptical approach towards the EU impacted upon the Brexit debate. By using the UK to constrain the EU's range of capabilities, the US encouraged London's misgivings about its value. This strategy rebounded to America's expense: during the referendum it sounded hollow when the Obama administration argued that Brexit would damage security. The US must take a share in the responsibility for the referendum result. It now faces an EU that will no longer be influenced directly by the UK. If Franco-German efforts do lead to greater EU defence cooperation it will cause friction with the principle of NATO's first right of refusal over a military operation. The US has to contend with the prospect of more complex institutional arrangements in Europe, but relatively little additional fighting capability.

\section{Multilateralism, Bilateralism and Brexit}

The US has championed a multilateral Atlanticist order: its rhetoric, outlined in numerous summit communiques, painted NATO and the EU as interlocking and mutually supportive organisations. During his time as a presidential contender, Senator Obama said that, 'America has no better partner than Europe.... Now is the time to join together, through ... strong institutions...' (Obama 2008). Yet America's pursuit of Atlanticism through the vehicle of multilateralism has co-existed with a readiness to engage in bilateralism when it has suited its interests. In this way the US has been willing to play off multilateralism and bilateralism. Posen describes this as 'behav(ing) in ways that seem capricious to its allies and friends' (2006). The UK has been the principal beneficiary of bilateralism through its 'Special Relationship' with the US. American policymakers have found it more convenient to enlist the UK in controversial policies, such as foreign military interventions, rather than construct US-European coalitions. During the era of George W. Bush, this was a pronounced feature of American policy as the administration wanted the freedom to act and rejected institutional or alliance constraints on its power.

In order to be able to act as America's foremost partner, the UK has been ready to sacrifice its position in Europe. This has resulted in opprobrium amongst its European allies. The UK has provided the US with a mechanism with which to dilute the 
homogeneity of the continent (Witney and Shapiro 2009, 6). By so doing the US has served to undermine the institutional arrangements on which Atlanticism was founded and which have been integral to the success of its post-Cold War political and security order.

In return, the UK has benefited from a form of 'patronage' in its relationship with America (Ikenberry 2004, 611). Although the UK has made its own significant contributions to these areas, it has enjoyed advantages out of proportion to its investments. This has been evident in four main policy spheres. The first of these has been the nuclear relationship, ostensibly committed to NATO, but in reality a means of ensuring the UK's independent nuclear status. Britain has been given successive generations of strategic nuclear weapons of a level of sophistication that it could not have developed alone. Second, it has been accorded unprecedented access to photoreconaissance imagery and signals intelligence. It is a part of the Five Eyes intelligence sharing relationship - the UK, US, Canada, Australia and New Zealand - that is unique amongst European countries. Third, it has been able to purchase conventional weapons systems at prices that have reflected only a fraction of the development costs. The F-35 Joint Strike Fighter, a fourth generation multi-role aircraft, is one such example. Lastly, the UK has enjoyed a close institutional relationship with America's armed forces that has enabled inter-operability in major military operations, such as the two Gulf Wars. This has extended to profiting from senior positions within NATO as well as providing the framework nation for the Allied Rapid Reaction Corps (ARRC).

In such ways the US has reinforced the UK's sense of being apart from and superior to its other European allies. It encouraged British political and military leaders to focus their attention disproportionately on security cooperation with the US rather than their European counterparts (Wallace 2005, 55). This view is contrary to those in the US that feared British membership of the EU would result in it cleaving away from America (Young 1998, 75). In actual fact, the UK sacrificed its opportunity to speak to the US on behalf of a group of EU countries (Howorth 2007, 172). This attitude was manifest in Prime Minister Tony Blair's perception that Britain was 'a pivotal power ...at the crux of ..alliances' (Blair 1999). It enabled 'Brexiteers' within the UK to argue that leaving the EU would provide the opportunity to cultivate a closer relationship with Washington.

However, the argument that Brexit could lead to a deepening of the Special Relationship misunderstands the role of the latter in US policy. Anglo-American cooperation has been a means of repaying British loyalty to Atlanticism, for helping to bring European allies into alignment with American policies. The UK was erroneously given the impression that 
there was a role for it, post-Brexit, as America's partner. The reality is that Brexit, in return for a stronger Special Relationship, offers little attraction to American policymakers. The UK is not in a position to increase significantly its defence spending or add to its capabilities. The difficulties that it faced at the NATO Summit in Wales in reaching the totemic $2 \%$ of GDP devoted to defence exposed the fallacy that the UK could ever partner America in a meaningful way. The limitations of the UK's capabilities were evident in the 2010 Strategic Defence and Security Review (SDSR) that inflicted significant cuts to the armed forces, including a $20 \%$ reduction in the size of the Army (Ministry of Defence 2010). In fact there were doubts even before Brexit about the UK's ability to maintain its existing patterns of cooperation with the US. ${ }^{i i}$

America's promotion of bilateral security and defence policy cooperation with the UK was conducted at the expense of both countries' multilateral relationships with the EU. America pursued a strategy that aggravated friction between its two key Atlanticist institutions, NATO and the EU. In so doing it contributed to the Brexit result that promises to frustrate America's broader multilateral goals and leaves it with a US-UK bilateral relationship of reduced value.

\section{The Implications of Brexit on a Global Role}

In the post-Cold War period, perhaps the key challenge for US-European relations has been to re-orientate security cooperation from its traditional East-West focus towards a more global agenda. In the words of Robert Gates (2007), there has been the need to re-fashion transatlantic relations to 'an era of global and unconventional threats'. While the US took responsibility for extra-European issues during the Cold War, it became less disposed to bear this burden after the demise of Soviet power. This has meant that the two sides have been required to find new ways of working together. To this end a 'New Transatlantic Agenda' (NTA) was negotiated in 1995 as an attempt to develop an innovative organizational framework (Winand and Philippart 2001). The NTA sought to counter the threat from 'rogue' states that defied the western-led order, the proliferation of weapons of mass destruction by state as well as non-state actors and from international terrorism (Gardner 1997).

Nevertheless, ambivalence has been evident in US attitudes towards the EU as a global security actor. On the one hand, America has been desirous of an EU contribution to address these threats, not least to reduce the burden on its own resources. The US was also mindful of the enhanced legitimacy it enjoyed if European allies were supportive of 
its policies (US National Security Strategy 2010, 41). On the other hand, Washington has been aware of its traditionally prickly relationship with Europe over global issues, due to differences of power and perspective between them. Recent examples of this prickly relationship have included transatlantic tensions over the conduct of the war in Afghanistan (Woodward 2010) and American criticism of European action in the 2011 Libyan intervention. Furthermore, the US has been reluctant to share its leadership position and freedom of manoeuvre with an organisation that it has regarded as incapable of concerted action on the global stage. The EU's intergovernmental approach to foreign policy has limited, and sometimes paralysed, its capacity to demonstrate political will and wield power. As a result the US has spurned it as a prospective partner. President Obama signalled the low priority he attached to the organisation by cancelling the US-EU summit in 2010 (Smith 2016).

In the face of these transatlantic tensions, the US has prized the role that the UK could play in focusing EU attention on international issues and orchestrating common action. Former US ambassador to the UK, Raymond Seitz, noted that Britain's 'outward-looking perspective' had been of benefit in America's relationship with Europe (Seitz 1993, 88). Similarly, President Obama stated that, 'one of the great values of having the UK in the EU is its leadership and strength on a whole host of global challenges' (Obama 2015). This global viewpoint stemmed from Britain's imperial history and long established engagement in international affairs. Its intimate and routine institutional conversation with the US has given it the capacity to understand and sympathise with many of America's points of view. This has included the latter's criticism of the EU's predisposition to focus on the security of its near abroad rather than global issues. The UK was able to play an important role as a conduit between the views of America and its European allies (Foreign and Commonwealth Office 2003, 26).

An example of this transatlantic role was the involvement of the UK in efforts to counter Iran's alleged nuclear weapons programme. The US was suspicious that two out of the three European countries leading the negotiations with Iran after 2003, France and Germany, had long-standing trade links with Tehran and feared lest commercial rather than security concerns might motivate them. As a consequence, UK leadership of the 'E3 ' negotiating effort went a considerable way to allay American concerns (Kutchesfahani 2006). By 2007 the E-3 had recognised that their efforts had not worked and they chose to bring the Iranian issue back to the United Nations - and by default, the US. Nevertheless, it had demonstrated how the UK could play a catalysing role amongst its allies and an interlocutor role across the Atlantic (Kortweg 2013). UK involvement in the negotiations continued after 2012, helping to bridge the gap between the back-channel 
US-Iranian dialogue in Oman (Clinton 2014, 436), and the publicly declared positions of the Permanent Five Members of the Security Council, plus Germany, negotiating in Geneva (Panorama 2016). The French government eventually adopted a tougher stance towards Tehran and it was the UK that helped to achieve a compromise position amongst the transatlantic allies.

Yet there has been a less constructive aspect of the US attitude towards the UK and EU global engagement. When the views of EU states have differed with those of America, the latter has often refused to invest the time and effort in creating a shared policy and has followed its own course. This has contributed to a perception that the US has abandoned its role as a benign hegemon and become indifferent towards the very institutionalist framework that it helped to create (Walt 1987). The Iraq War of 2003 was the foremost example of this approach. The US drew the UK into bilateral cooperation and in so doing limited the role that London could play in alliance management. The fallout from this policy was considerable: not only did the US provoke a soft power balancing response by France and Germany (Paul 2005, 65), but the UK was detached from the European mainstream (Wallace and Oliver 2005, 153). This contributed to the Brexit decision where UK voters were fed an image of their country as a natural ally of America, rather than a European power.

Brexit will limit the contribution of the UK to transatlantic global security cooperation: it will no longer be able to serve as an interlocutor. It is also likely to be preoccupied with the process and aftermath of Brexit. Much of the attention of the UK's best public servants will be dominated by the complex negotiations to extricate the country from the Union and to agree new trading arrangements with countries around the world. This bolsters a wider fear in Washington that Britain's decision to leave the EU signals a wider retreat from its sense of a global mission. It is seen as part of a trend of UK actions that started with its premature withdrawal from both Iraq and Afghanistan and later led to the Parliamentary vote in 2013 against intervention in Syria (Oliver and Williams 2016, 555-6). Former Secretary of Defense Ashton Carter echoed these misgivings and cautioned lest Britain retreat from its status as a country of influence within the world (Carter 2015).

It would be an exaggeration to say that the US will no longer value Britain as a diplomatic actor. After all, the UK retains a permanent seat on the United Nations Security Council, membership of the Group of Seven leading industrial nations, the G-20 and an array of links with countries in the world through the Commonwealth. Britain will maintain strong bilateral relations with its European allies after Brexit and may try to 
build a new cooperative relationship with the EU. Prime Minister Theresa May's government has denied any contraction of Britain's overseas role. They cite defence diplomacy, the multitude of British military missions around the world and the sending of additional troops to the Baltic states as evidence of the country's intention to remain engaged around the world (Peach 2016). Some in the US have argued that the role the UK has traditionally fulfilled as America's voice within the EU served nobody's interests (Bolton 2016). Bolton argues that the election of US President Donald Trump offers an opportunity for the UK to show more, rather than less, leadership within the transatlantic context. This is an echo, from the right of the American political spectrum, that Brexit will free up the UK to act on the world stage.

However, there can be no denying that post-Brexit the UK will be an actor of diminished stature, unable to use the EU to enhance its diplomacy. The result for the US of Brexit will be an EU that is likely be more insular, preoccupied with its own internal development and less minded to look beyond its frontiers (Greenstock 2009). Britain's departure leaves Washington less well informed about European views and increases the likelihood of transatlantic discord over international security issues. There is a higher possibility that Europe will define its positions on global issues in contradiction with those of America. France will be the only member of the Union with both a global perspective and matching military and diplomatic capabilities. But France is a country with whom the US has traditionally differed on intra and extra-European security issues. Brexit offers Paris the opportunity to realise objectives that seek EU autonomy from American power.

\section{Conclusion}

This article has argued that the US deserves a significant share of the responsibility for the UK decision to leave the EU. Whilst the Obama administration was voluble in its opposition to British withdrawal, this rang hollow in the light of the attitudes of previous administrations towards the development of EU security and defence integration. The US had long been concerned that the Union would develop either into a security rival or an ally unworthy of American protection. In the process of denigrating and obstructing EU defence efforts, America stimulated pressures within the UK for withdrawal and made it harder for the 'Remainers' to argue that valuable security interests would be forfeited.

The Brexit debate exposed internal contradictions in US policies towards the UK and the EU. America's 'Atlanticist' order had served its interests by ensuring its leadership role in the continent's security. Yet the US had come to manage the increasingly complex 
multilateral relationship with its EU allies with the aid of a special bilateral relationship with the UK. This had been used to dilute and veto initiatives that would have rendered the EU more autonomous and capable. America rewarded the UK with benefits and a status that encouraged it to see Europe as of secondary importance to Britain's relationship with the US. This increased the UK's scepticism of CSDP and prepared the ground for Brexit. In the aftermath of the decision to leave, the Special Relationship will not compensate America because the UK lacks the resources that could make it the putative partner of the US. Whilst the Obama administration moved quickly after the referendum to reaffirm its Special Relationship with the UK (Roberts and Smith 2016), there is no concealing the fact that its value has diminished.

At a time when the US is facing a more complex and risky security environment it will experience an EU less able to contribute towards American goals in two main ways. First, European defence capacity will be diminished by the UK's departure even if EU countries promote closer military integration. Although Britain will remain committed to the security of Europe, and an active member of NATO, the institutional frameworks in which it can contribute to security and defence will have narrowed. It will take time for the UK to divorce the EU and for its bilateral relationships, with countries such as France and Germany, to be augmented. The US will face a continent more preoccupied with its own internal debates and will lose London's capacity to galvanise Europe's military capabilities. Second, an EU without the influence of the UK will be predisposed to act autonomously of America and less disposed to contribute to global security issues. Brexit will lift the brake from those countries eager to duplicate some of NATO's strengths, such as a headquarters capacity.

The Brexit decision increases the potential for stalemate and estrangement between the two sides of the Atlantic. Whether this extends to a broader threat to that Euro-Atlantic order is too early to gauge. In the eyes of pessimists, Brexit risks de-stabilizing the EU and creating a momentum to leave that other countries may imitate. If this were to occur then even the NATO pillar of the Atlantic order could be undermined. Such a warning was evoked by Lieutenant General Frederick Hodges, the commander of US forces in Europe, who cautioned that the EU could disintegrate, with major ramifications for NATO (Sims 2016). Such concerns have been exacerbated by the accession of Donald Trump to the US presidency: as a candidate he called the Alliance 'obsolete' and questioned his country's commitment to the Article $V$ collective defence guarantee. Even in the absence of such a worse-case scenario, Brexit could stimulate the process of a multi-speed Europe with an inner core of countries integrating more closely. This is an outcome about which the US would feel uneasy as it would have no influence over the 
direction that this closer integration would take. In sum, America's policies have returned to haunt them in the Brexit result as the US contributed to a result that it had sought to avoid.

\section{Bibliography}

Albright, M. (1998) 'The right balance will secure NATO's future', The Financial Times, 7 December.

Anagnostakis, D. (2014) 'Cooperation between the European Union and the United States on Internal Security after 2001: The Negotiation of a Nascent Regime', PhD Thesis, University of Nottingham.

Applebaum, A. (2016) 'More special in Europe', The Economist, 23 April.

Blair, T. (1999) Speech by Prime Minister Tony Blair, 'The UK becoming a pivotal power', Mansion House, London, BBC News online, 22 November, http://news.bbc.co.uk/1/hi/uk politics/532620.stm (Accessed 3 October 2016).

Blair, A. (2010) A Journey, Hutchinson, London.

Bolton, J. (2016) 'Together a Trump led US and Brexit Britain can restore NATO and the West', 29 September, http://www.aei.org/publication/together-a-trump-led-us-andbrexit-britain-can-restore-nato-and-the-west. (Accessed 13 December 2016).

Borger, J., Traynor, I. and Watt, N. (2013) 'Britain should stay in the European Union, says Obama administration', The Guardian On-line, 10 January, http://www.theguardian.com/world/2013/jan/09/us-warns-uk-european-union (Accessed 23 February 2016)

Brimmer, E. (2007) 'Seeing blue: American visions of the European Union', Chaillot Paper 105, EU Institute for Security Studies, Paris, September.

Brooks, S. and Wohlforth, W. (2005) 'Hard times for soft balancing', International Security, 30, 1 Summer, 72-108.

Brzezinski, Z., Scowcroft, B., Schultz, S., Allen, R., Gates, R., Cohen, W., Albright, M., Perry, W., Hadley, S., Jones, J., Donilon T. and Panetta, L. (2016) 'Special Relationship and the UK's clout in Europe', The Times, 10 May.

Byrne, A. (2016) 'US Elite Discourse on the EU as a Security Actor', PhD thesis, University of Edinburgh.

Cameron, D. (2013) 'The future of the EU and the UK's relationship with it', Speech by Prime Minister David Cameron, Bloomberg, London, 23 January. https://www.gov.uk/government/speeches/eu-speech-at-bloomberg (Accessed 11 June 2015).

Cameron, D. (2015) 'Prime Minister's Speech on Europe', Chatham House, London, 10 November, https://www.gov.uk/government/speeches/prime-ministers-speech-oneurope. (Accessed 1 April 2016).

Carter, A. (2015) 'US Defence Secretary warns against UK armed forces cuts', BBC News Service, 1 June. http://www.bbc.co.uk/news/uk-32955231 (Accessed 8 July 2015). 
Chalmers, M. (2017) 'UK Foreign and Security Policy after Brexit', RUSI Briefing Paper, January, http rusi.org. (Accessed 12 January 2017).

Clinton, H. (2014) Hard Choices, London: Simon and Schuster.

Coffey, L. (2013) 'EU defense integration: Undermining NATO, Transatlantic relations, and Europe's security' Heritage Institution, http://www.heritage.org/research/reports/2013/06/eu-defense-integration-underminingnato-transatlantic-relations-and-europes-security. (Accessed 25 February 2016)

Deudney, D. and Ikenberry, G. J. (1999) 'The nature and sources of liberal international order', Review of International Studies, 25, 179-196.

Dunne, T. (2004) '"When the shooting starts": Atlanticism in British strategy', International Affairs, 80, 5, October, 893-909.

Emmot, R. (2016) 'Germany, France to revive defence but no plans for EU army, Reuters, 3 June, www.reuters.com/article/us-europe-wwwdefence-idUSKCNOYP11B (Accessed 8 July 2016).

European Commission (2016) 'Speech of EU Commission President Jean-Claude Juncker, 'Towards a better Europe - a Europe that protects, empowers and defends', Speech no. 16/3043, Strasbourg, 14 September, http://europa.eu/rapid/press-release_SPEECH-163043_en.htm (Accessed 11 October 2016).

EU Global Strategy (2016) Priorities of the EU Global Strategy, https://europa.eu/globalstrategy/en/priorities-eu-global-strategy (Accessed 12 January 2017)

Foreign and Commonwealth Office (2003) 'UK international priorities: a strategy for the $\mathrm{FCO}^{\prime}$, London, December, http://image.quardian.co.uk/sysfiles/Politics/documents/2003/12/02/FCOStrategyFullFinal.pdf (Accessed 7 May 2015).

Gardiner, N., Coffey, L. and Bromund, T. (2015) 'A "Brexit" from the EU will strengthen, not weaken, the Special Relationship, and will provide momentum for the negotiation of a U.S.-UK free trade area'. http://www.heritage.org/research/reports/2015/01/davidcamerons-visit-to-washington-an-important-opportunity-to-renew-angloamericanleadership. (Accessed 25 February 2016)

Gardner, A. (1997) A New Era in US-EU Relations? The Clinton Administration and the New Transatlantic Agenda, Aldershot: Avebury Press.

Gates, R. (2011) Speech by Defense Secretary Robert Gates at the Security and Defence Agenda, $\quad$ Brussels, $10 \quad$ June, http://archive.defense.gov/Transcripts/Transcript.aspx?TranscriptID $=4839$ (Accessed 13 November 2016).

Gates, R. (2007) Secretary of Defense Robert Gates, Speech to the 43rd Munich Conference on Security Policy, Munich, 10 February.

George, S. (1988) An Awkward Partner: Britain in the European Community, Oxford, Oxford University Press.

Glencross, A. (2015) 'Why a British referendum on EU membership will not solve the European question', International Affairs, 91, 2, 303-317. 
Greenstock, J. (2009) Evidence to the Foreign Affairs Select Committee Report, Global Security: UK-US Relations, Evidence 40, London, 2 December.

Hirschman, A. (1970) Exit Voice and Loyalty: Responses to Decline in Firms, Organizations and States, Boston: Harvard University Press.

Howorth, J. (2007) Security and Defence Policy in the European Union, Basingstoke: Palgrave Macmillan.

Ikenberry, G. J. (1988-89) 'Institutions, strategic restraint and the persistence of American postwar order, International Security, 23, 3, 43-78.

Ikenberry, G. J. (2001) Interview with Robert Zoellick, US State Department, cited in After Victory: Institutions, Strategic Restraint and the Rebuilding of Order after Major Wars, Princeton: Princeton University Press.

Ikenberry, G. J. (2004) 'Liberalism and Empire: Logics of order in the American unipolar age', Review of International Studies, 30, 4, October, 609-630.

Joffe, J. (1986) 'Europe's American pacifier', Foreign Policy, Spring, 64-87.

Johnston, S. (2016) 'The EU's CSDP; an (objective) UK perspective', 27 March, http://www.europeangeostrategy.org/2016/03/the-eus-csdp-an-objective-ukperspective/ (Accessed 1 April 2016).

Kortweg, R. (2013) 'The EU and Iran', Centre for European Reform online, March, https://www.cer.org.uk/search/site/iran (Accessed 16 May 2016).

Kupchan, S. (1998) 'After Pax Americana: Benign power, regional integration and the sources of a stable multipolarity', International Security, 23, 2, 40-79.

Kutchesfahani, S. (2006) 'Iran's nuclear challenge and European diplomacy', European Policy Centre Paper 46, Brussels, March.

Leigh, M. (2015) 'The EU: Made in Britain', German Marshall Fund, 19 January, http://www.gmfus.org (Accessed 16 December 2015).

Lundestad, G. (2003) The United States and Western Europe since 1945: From 'Empire' by Invitation to Transatlantic Drift, Oxford, Oxford University Press.

Marsh, S. (2013) 'The Anglo-American defence relationship' in Dobson, A. and Marsh, S. (eds) Anglo-American Relations: Contemporary Perspectives, Abingdon: Routledge.

Mearsheimer, J. (2001) 'The future of the American pacifier', Foreign Affairs, September/October.

Miliband, D. (2010) Response of the Foreign Secretary, David Milliband to the House of Commons, Foreign Affairs Select Committee Report - Global Security: UK-US Relations. Third Special Report of Session 2009-10, 6 April, London: The Stationery Office.

Ministry of Defence (2010) Securing Britain in an Age of Uncertainty: The Strategic Defence and Security Review, Command 7948, London: The Stationery Office, 19 October.

Molling, C. (2015) 'Weather reports, defense budgets, and military power', Policy Brief, The German Marshall Fund, 14 September, 
bhttp://www.gmfus.org/publications/weather-reports-defense-budgets-and-militarypower (Accessed 10 November 2016).

Obama, B. (2008) 'People of the World', Speech by Barack Obama in Berlin, 24 July, CNN Politics, http://edition.cnn.com/2008/POLITICS/07/24/obama.words. (Accessed 10 November 2016).

Obama, B. (2015) G7: Statement by David Cameron and Barack Obama, Bavaria, 7 June, https://www.gov.uk/government/speeches/g7-statement-by-david-cameron-andbarack-obama (Accessed 23 January 2016).

Obama, B. (2016) Speech of President Barack Obama to both houses of Parliament, Westminster Hall, 25 May, http://www.bbc.co.uk/news/uk-politics-13549927 (Accessed 3 July 2016).

Oliver, T. (2015) 'To be or not to be in Europe: is that the question? Britain's European question and an in/out referendum', International Affairs, 91, 1, 77-91.

Oliver, T. and Williams, M. (2016) 'Special relationships in flux: Brexit and the future of the US-EU and US-UK relationships', International Affairs, 92, 3, 547-567.

Panorama (2016) 'Inside Obama's Whitehouse: "Don't screw it up"', episode 3, screened 30 October, BBC Two.

Pape, R. (2005) 'Soft balancing against the United States', International Security, 30, 1, Summer, 7-45.

Paul, T. V. (2005) 'Soft balancing in the age of US primacy', International Security, 30, $1,46-71$.

Peach, S. (2016) Annual lecture by the Chief of the Defence Staff, Sir Stuart Peach, Royal United Services Institute, 14 December, https://rusi.org/event/CDS-Lecture-2016 (Accessed 12 January 2016).

Philipart, E. and Winand, P. (2001) (eds) Ever Closer Partnership: Policy-making in USEU Relations, Brussels: PIE Peter Lang.

Posen, B. 'EU security and defence policy: Response to unipolarity? Security Studies, 15, 2, 2006, 149-86.

Prospect Magazine Online (2016) 'Brexit would not damage UK security', April, http://www.prospectmagazine.co.uk/opinions/brexit-would-not-damage-uk-security (Accessed 1 April 2016)

Rees, W. (2011) The US-EU Security Relationship: The Tensions between a European and a Global Agenda, Basingstoke: Palgrave Macmillan.

Risse-Kappen, T. (1995) Cooperation among Democracies: The European Influence on US Foreign Policy, Princeton: Princeton University Press.

Roberts, D. and Smith, D. (2016) 'US and UK Special Relationship is 'enduring', Obama says after Brexit', The Guardian, 24 June 2016, https://www.theguardian.com/politics/2016/jun/24/brexit-vote-impact-on-us-donaldtrump-election-2016. (Accessed 6 January 2017).

Seitz, R. (1993) 'Britain and America: towards strategic coincidence', The World Today, May, 85-88. 
Serfaty, S. (1997) Stay the Course: European Unity and Atlantic Solidarity, Westport: Praeger.

Sims, A. (2016) 'EU referendum: "Brexit could weaken NATO alliance" warns US general', The Independent Online, 15 March, http://www.independent.co.uk/news/uk/politics/eu-referendum-brexit-could-weakennato-alliance-warns-us-general-a6931731.html (Accessed 17 March 2016).

Smith, J. (2016) Testimony by Julianne Smith of the Center for a New American Security, to the US Senate Committee on Foreign Relations, 'Strains on the European Union: Implications for American Foreign Policy', Washington DC, 3 February 3. (Accessed 26 April 2016).

Sparrow, A. (2015) 'Jean-Claude Juncker calls for EU army', The Guardian, 8 March, https://www.theguardian.com/world/2015/mar/08/jean-claude-juncker-calls-for-euarmy-european-commission-miltary. (Accessed 8 July 2016).

Times, The (2016) Theresa May interview, 23 March.

Treaty between the United Kingdom of Great Britain and Northern Ireland and the French Republic for Defence and Security Cooperation, Command 8174, 2 November 2010

https://www.gov.uk/government/uploads/system/uploads/attachment data/file/238153/ 8174.pdf (Accessed 12 October 2016).

US National Security 2010: https://www.whitehouse.gov/sites/default/files/rss viewer/national security strategy.pd f. (Accessed 13 March 2016).

Wallace, W. (2005) 'The collapse of British foreign policy', International Affairs, 81, 1, 53-68.

Wallace, W. and Oliver, T. (2005) 'A bridge too far: the United Kingdom and the transatlantic relationship' in Andrews, D. (ed) The Atlantic Alliance under Stress: USEuropean Relations after Iraq, Cambridge: Cambridge University Press.

Walt, S. (1987) The Origins of Alliances, Ithaca, New York, Cornell University Press.

Waltz, K. (2000) 'Structural Realism after the Cold War', International Security, 25, 1, Summer, 5-41.

Waterfield, B. and Willan, P. (2016) 'Brussels seizes chance to create an EU army', The Times, 9 September.

Weaver, M. (2008) 'US considers tighter travel rules for European visitors', The Guardian, 16 January, https://www.theguardian.com/world/2008/jan/16/terrorism.eu. (Accessed 21 January 2008).

Winand, P. and Philippart, E. (2001) 'From 'equal partnership' to the 'New Transatlantic Agenda': Enduring features and successive forms of the US-EU relationship,' in Winand, P. and Philippart, E. (eds) Ever Closer Partnership: Policy-making in US-EU Relations, Brussels: PIE Peter Lang.

Wintour, P. (2016) 'Cameron could not have asked for more from Obama's Brexit warning' The Guardian Online, 22 April, 
http://www.theguardian.com/politics/2016/apr/22/cameron-could-not-have-asked-formore-from-obamas-brexit-warning (Accessed 26 April 2016).

Witney, N. and Shapiro, J. (2009) 'Towards a post-American Europe: A power audit of EU-US relations', European Council on Foreign Relations, London, 2 November, http://www.ecfr.eu/publications/summary/towards_a_post_american_europe_a_power_ audit_of_eu_us_. (Accessed 6 July 2016).

Witney, N. (2016) 'What would Brexit mean for Britain's national security?' Policy Network, $21 \quad$ January, http://www.policynetwork.net/pno_detail.aspx?ID $=5053 \&$ title $=$ What + would + Brexit + mean + for + Britain $\%$ e 2\%80\%99s+national+security\%3f (accessed 1 April 2016).

Woodward, B. (2010) Obama's Wars, London: Simon and Schuster.

Young, H. (1998) This Blessed Plot. Britain and Europe from Churchill to Blair, London: Macmillan.

\section{Notes}

'There has been a voluminous literature debating the existence of a US-UK 'Special Relationship'. See for example, Baylis, J. (1997) Anglo-American Relations since 1939: The Enduring Alliance, Manchester: Manchester University Press; Dumbrell, J. (2006) A Special Relationship: Anglo-American Relations from the Cold War to Iraq, Basingstoke: Palgrave and Dobson, A. and Marsh, S. (2013) (eds) Anglo-American Relations: Contemporary Perspectives, Abingdon: Routledge.

ii In 2015 during testimony to Congress, former US Army Chief of Staff General Ray Odierno warned that in the past the UK had fielded a division to operate alongside US divisions, but that this might shrink to just a British brigade operating inside a larger US formation (BBC News (2015) 'UK defence spending "concerns" US Army chief Raymond Odierno', 2 March, http://www.bbc.co.uk/news/uk-31688929 (Accessed 4 /5/2015). 